\title{
Community Changes in Pregnancy Services during the Covid-19 Pandemic
}

\author{
Sri Hilmi Pujihartati ${ }^{1}$, Argyo Demartoto ${ }^{2}$ \\ ${ }^{1}$ Departement of Sociology, Faculty of Social and Political Sciences, Universitas Sebelas Maret \\ (email: srihilmi@staff.uns.ac.id) \\ ${ }^{2}$ Universitas Sebelas Maret
}

\begin{abstract}
This article will discuss how to adjust and the condition of services in health facilities, especially for pregnant women during the pandemic. The method used is literature study to obtain data and finally it will be condensed into a conclusion. The theory of behavior change is the basis for analyzing changes in community behavior in health services during the Covid19 pandemic. The purpose of this paper is to provide an understanding of how the actual situation in society, especially in the health sector of pregnant women during the Covid-19 pandemic is. The results showed that in the health sector there were considerable changes. This change is not only carried out by medical personnel, but also needs to be balanced by public awareness. Due to this pandemic, people must pay more attention to themselves, especially for pregnant women. For pregnant women, it can be done through online examinations and consultations with medical personnel or face to face with strict health protocols. In addition, monitoring can also be carried out independently from home by referring to the $\mathrm{MCH}$ handbook. Understanding and knowledge of pregnant women is needed in addition to reducing the intensity of pregnancy checks. For this reason, pregnant women need to behave in a healthy way by referring to the policies issued by the Indonesian Ministry of Health. Optimizing the health of pregnant women is very much needed in reducing the incidence of Covid-19 and reducing maternal anxiety during the Covid-19 pandemic.
\end{abstract}

\section{Keywords:}

Covid-19; pregnancy; health

\section{Introduction}

Since the WHO (World Health Organization) declared that the corona virus disease (Covid-19) is a global health emergency or pandemic, the Indonesian government has implemented social distancing measures with strict health protocols (use of hand sanitizers, maintain distance, increase endurance, maintain cleanliness). body, more stringent anticipation of individuals who have comorbid). All of these rules are enforced to suppress COVID-19 cases (Buana D.R., 2020). 
The Covid-19 pandemic that has occurred since the beginning of 2020 has forced us to be able to adapt to different rules, norms, policies, and procedures for an activity. Many new regulations have emerged that prohibit people from gathering and doing face-to-face activities, as well as policies on health services. Society also experiences various changes in it, especially in dealing with the pandemic during pregnancy. Changes in the health sector occur by taking into account other fields, for example economic progress that will facilitate all activities that are prohibited from being carried out face-to-face.

Behavior change theory explains every condition that is befalling society. As in the current state of the Covid-19 pandemic, the community has an important role to play in stopping the spread of the Covid-19 virus. Given that the transmission of Covid-19 is a droplet infection from individual to individual, the principle of prevention can be carried out with an individual approach and a community approach. Individual approaches include doing 3M (washing hands, wearing masks, keeping a distance). Meanwhile, the community approach includes prevention efforts, case finding efforts, and effective handling (Kemenkes RI, 2020). Michie et al (2020 in Ichsan, 2020) explain one form of advocacy and behavior aimed at the public (UK government) to deal with the Covid-19 pandemic, namely the behavioral change theory approach. The UK government itself has a draft guideline for social distancing and protection for vulnerable people (shielding of vulnerable people) against Covid-19. Based on the results of research that has been done, obtained information:

1. The theory of behavior change can be used as a practical and systematic framework to understand, analyze, and provide recommendations to those who issue regulations for the benefit of the wider community.

2. The theory of behavior change can be used to detect obstacles that may be faced by the state in implementing regulations related to the prevention of Covid-19.

3. Frequent and infrequent behavioral changes can be seen

4. The results of empirical research can be used as an illustration of an intervention based on a behavioral change framework.

According to Selo Soemardjan in Goa (2017) that social change is a change that occurs in community interactions and will affect the social system which includes attitudes, behavior, values in society. Behavior in society can be seen and assessed when it has been carried out in large numbers of people. Individuals can behave according to internal factors or other people 
or the environment. During a pandemic like this, environmental conditions, positive confirmed cases, and news broadcast in the mass media can also influence people's behavior.

Society will always change, experience movement, and develop. All these changes can occur due to internal and external factors from the community. This change cannot be avoided, what can be done is to follow the changes while still paying attention to the balance in society. If this change occurs followed by the ability to follow from other parties, there will be no negative impact. It is different if change is not followed by the ability to follow, this will certainly be problematic because it will be able to trigger conflict in the community itself.

Facing pregnancy and childbirth is something that requires special attention, especially in this Covid-19 pandemic situation, which is certainly more challenging. However, all difficulties will still be overcome, and pregnant women are required to undergo each process in a comfortable and safe condition. A pregnant woman has the right to get quality health and mental services, both before, during, and after giving birth. For this reason, every pregnant woman during a pandemic is recommended to do:

1. As much as possible to stay at home (stay at home)

2. Maintain personal hygiene and wash hands regularly

3. Avoid people who are sick

4. Consume nutritious food and vitamins

5. Monitor fetal movement

6. Monitor the symptoms of Covid-19 infection (fever, cough, runny nose, sore throat, shortness of breath, diarrhea)

7. Knowing the signs of an emergency in pregnant women as mentioned above

8. Conducting tele clinical consultations with doctors

9. Plan carefully for labor

10. Support from family

The risk of Covid-19 complications is higher for people with vulnerable groups. The vulnerable groups in question are those who are elderly, individuals who have weaknesses, especially chronic diseases, and pregnant women. Obstetrics and Gynecology Specialist at Semen Padang Hospital (SPH), dr. Primadella Fegita, Sp.OG, stated that pregnant women are more susceptible to Covid-19 because cell activity in the mother's body during pregnancy will decrease, causing weakened immunity. 
Pradana, et al (2020), said that physiological and immunological changes by pregnant women can have systemic effects that increase the risk of obstetric complications from respiratory infections in pregnant women. The social distancing policy also applies to pregnant women, in order to limit activities with the outside environment. One of the risks of pregnant women contracting Covid-19 is during pregnancy check-ups at clinics or hospitals. For this reason, services for pregnant women need alternatives that do not harm any party, both pregnant women themselves and midwives or doctors.

According to Priyanti, et al. (2020) maternity service is an activity for mothers that is carried out routinely and repeatedly with the aim of providing support to pregnant women, consultation on physiological, behavioral, biomedical, and psychological issues to realize a successful delivery and healthy mothers and children. Efforts to provide services for pregnant women are carried out by medical personnel with good cooperation in the community. Good cooperation must be established from pregnant women because they are the targets of success in the service of pregnant women.

According to Government Regulation Number 61 of 2014 maternal health services include health services for the period before pregnancy, pregnancy, childbirth and after childbirth, pregnancy management, contraceptive and sexual health services and reproductive system health services (Government Regulation of the Republic of Indonesia, 2014). The challenge of midwifery services during the Covid-19 pandemic is the knowledge of mothers and families regarding Covid-19 (Simbolon, et al, 2021).

This study will explain changes in society, especially in pregnancy services during the Covid-19 pandemic. The changes that occur during the Covid-19 pandemic must inevitably be accepted by the community, especially for pregnant women in checking their pregnancy for the health of the mother and baby. Apart from that, it is also necessary to take policy steps from health workers which of course also need cooperation from pregnant women.

\section{Methods}

To compose this paper, the author conducted a library research to obtain secondary data from journals and used data from relevant agencies to support the validity of the data. Literature study is a method of collecting information and data through materials in the library, such as documents, books, photographs, pictures, historical stories, and electronic 
documents that can support the writing process (Mardalis, 1999 in Mirzaqon \& Budi). Literature studies are also carried out by studying several reference books and the results of previous research similar. According to Sugiyono (2012), literature study is a theoretical study of references and other scientific literature related to culture, values, and norms that develop in the social situation under study.

\section{Results and Discussion}

Based on data and information obtained through several literatures, researchers found that during the pandemic, pregnant women's visits decreased a lot because of concerns about going out of the house. One of them, in the independent practice of midwives in the Bandung area, it was found that the decrease in visits by pregnant women was more than $50 \%$. Of the pregnant women who are still doing the examination, 20\% have not visited more than four meetings (Rofiasari, 2020).

According to Rachmawati, et al. (2017), services during the preparation for childbirth are carried out to prevent bad risks that may occur for pregnant women, especially those with high risk. The government stipulates a minimum of four visits during pregnancy as a standard for pregnancy services.

According to the Ministry of Health (2012), the minimum frequency of examination visits for pregnant women is four times. The services provided include measurement of body weight, blood pressure, abdominal circumference measurement, giving vitamins and iron, immunization, HIV/AIDS checks, to counseling regarding problems felt during pregnancy.

According to Zeithaml (2010, in Jati, 2014), there are five criteria in determining the quality of services for pregnant women, including ability, responsiveness, assurance, attention, to direct evidence. The ability of medical personnel to serve patients is an important thing to consider. Then, how is the response and response of medical personnel when there are problems. What is meant by guarantee is the ethics of medical personnel in serving patients. Furthermore, care that arises from the heart to help pregnant women and equipment for handling medical personnel must also be needed.

During the pandemic, for examination services for pregnant women with the standard "Every pregnant woman gets services according to standards in the area where the pregnant woman stays during pregnancy" (Kemenkes RI, 2020). Each region has its own policy 
according to the needs and ability of the region to meet its needs. Health centers and hospitals, as well as other health facilities will receive subsidies for services for pregnant women. This of course must be used as well as possible by medical personnel and by pregnant women themselves.

According to research by Nurrizka, et al. (2021), during the pandemic, pregnant women prefer to have their womb checked at a hospital health facility. For the Greater Jakarta area, the largest proportion is pregnant women in Depok, which is $60 \%$ of the total number of pregnant women. According to the researcher, Puskesmas need to increase the effectiveness of examinations so that pregnant women do not experience queues that cause concerns regarding the spread of the COVID-19 virus for pregnant women who are carrying out pregnancy tests.

According to drg. Saraswati, MPH., Director of Primary Health Services (2020), in the early days of the pandemic, health services, especially patients with positive cases of COVID19, were centered in hospitals. However, the increasing number of cases prompted the government to make other policies, namely by allowing self-care for patients with more favorable conditions. Many patients, including pregnant women, require treatment from the closest medical personnel from their isolation sites. So, the Puskesmas took part in community service activities confirmed positive for COVID-19.

The widespread spread of the COVID-19 virus in various countries has caused many negative impacts, especially for human psychology. Fears about the consequences and spread of the COVID-19 virus are a shadow for humans. Its continuous spread causes anxiety for many individuals to carry out activities, especially to leave the house and interact with many people (Shigemura et al, 2020).

According to Baro'ah (2020), the fears that arise will have an impact on the emergence of anxiety for pregnant women. It is important to provide counseling to pregnant women so that they are able to understand the steps that minimize the spread of the COVID-19 virus while they are pregnant and give birth in the future. The knowledge possessed by pregnant women can help them think in making decisions about how they should behave in order to still be able to meet their physical, psychological, and other needs during the pandemic. One of the factors that can influence the understanding of pregnant women in the counseling process is work, education, and age (Damayanti, 2012). 
According to Tantona (2020), that during the pandemic, anxiety in pregnant women tends to increase. For example, in Banyumas Regency, in 28 pregnant women, $75 \%$ of respondents experienced anxiety. Anxiety ranges from mild to severe. So, pregnant women become more careful in their activities outside the house.

During a pandemic like this, pregnant women must adapt so as not to experience anxiety which is actually dangerous for pregnant women themselves. There are various forms of adaptation, for example by diligently washing hands, using masks (better if 2 layers), bathing after traveling, conducting routine checks, and also taking advantage of technological advances in consulting with medical personnel (Rahmawati \& Sutrisno).

For pregnant women who are nearing delivery, they are required to carry out laboratory tests to ensure that they are free from COVID-19. If the results are found to be positive for COVID-19, then the delivery will be carried out with stricter health protocols that are much more serious. In addition to health protocols, the number of medical personnel who help will also increase to speed up the birth process and immediately cut off contact with positive COVID-19 patients. This can cause new concerns for pregnant women in the New Normal period (Rahmawati \& Sutrisno, 2020).

The immunity of pregnant women is also an important concern, because they are considered more susceptible to contracting the COVID-19 virus. Physical changes that occur during pregnancy also affect the health of pregnant women, if not maintained will be able to interfere with the immune system of pregnant women. If pregnant women are exposed to the COVID-19 virus, healing requires more attention from medical personnel (Sutton, et al., 2020).

The government has set a new rule in the service of pregnant women during the Covid-19 pandemic that there are differences in examination activities from the period before the pandemic, which are the differences, among others.

The division according to zones as above is in accordance with the Guidelines for Antenatal Services, Childbirth, Postpartum and Newborns in the Era of Adaptation to New Habits (Kemenkes RI, 2020). Problems experienced by medical personnel in handling patients, especially pregnant women during the pandemic (Nurjami, 2020):

1. Difficulty in fulfilling Personal Protective Equipment (PPE) and materials for infection prevention. 
2. The patient's awareness of self-protection is low by wearing a mask and washing hands in running water.

3. Patients who are confirmed positive for COVID-19 but are not honest with the midwife, causing concern for medical personnel.

4. Limited number of Rapid test supplies following local policies.

5. Mother is afraid to visit the Midwife's Independent Practice clinic, Puskesmas or Hospital.

6. Independent Practice Midwives experienced a decrease in the number of patients (immunization, family planning, and ANC).

7. There are patients who still come to ignore health protocols (not wearing masks, midwives must provide masks for patients and companions).

According to Anshari \& Wahyuni (2020), the educational process can be done virtually, without having to meet face to face, especially during a pandemic like this. Various applications are offered to conduct virtual meetings, such as Gmeet, Zoom, and WhatsApp. The limitations that occur during the pandemic force all parties to rack their brains so that activities can continue even though they are not like before the pandemic. Therefore, virtual meetings are highly recommended, especially for areas with high confirmed cases of COVID19.

In Gumpang Kartasura Village, a way to deal with the changes that occur during the pandemic, Gumpang Health Center medical personnel conduct online counseling, using WhatsApp group media, distributing flyers to the community, to making videos for education for pregnant women to facilitate the delivery of medical personnel. In addition to using online media, medical officers from the local Puskesmas also conduct door to door counseling to pregnant women's homes to check the content and provide counseling according to the needs of pregnant women (Indriawan, et al. 2021).

Concerns of Pregnant Women in the Pandemic Period, according to Hall et al. (2021):

1. Changes that occur with medical personnel.

2. Must apply health protocols by wearing masks and diligently washing hands.

3. When consulting with medical personnel, unable to grasp the meaning conveyed properly. 
4. The use of masks that cover other people's expressions, which then creates a sense of worry and suspicion.

5. Difficulty breathing when wearing a mask.

6. Changes in the form of inspection.

7. Isolate if exposed to the COVID-19 virus.

8. Loss of concern from the people around.

9. When giving birth, the wait is limited.

10. Worried about being exposed to the COVID-19 virus.

11. Worried about being treated separately from the baby who was born.

12. Limited choice of place to give birth.

13. Hospitalization.

It is important for pregnant women to take antenatal classes online to stay informed about pregnancy and childbirth during the COVID-19 pandemic. This activity is very beneficial for pregnant women. According to research conducted in Turkey, online education can reduce anxiety for pregnant women and reduce the pressure they feel. In this activity, pregnant women can check whether news about COVID-19 is true or just disseminated to trigger public concern. (Derya et al., 2021)

According to Irianti B, et al in their research in 2015 that Midwives are recognized as responsible and accountable professionals, working in partnership with women to provide support, care, advice during pregnancy, childbirth and the puerperium, including newborns. The care provided includes delivery support, prevention, detection of complications in mother and child, accessing medical care or other appropriate assistance and carrying out emergency measures.

The COVID-19 pandemic can affect the psychology of pregnant women, it is important to provide extra services for pregnant women by providing special assistance from experts. By getting assistance, the risk of experiencing depression will be reduced and pregnant women are expected to continue to feel relaxed without worrying too much about pregnancy and childbirth (Choi et al., 2020).

In addition, physical health management is also very necessary during the pandemic. Physical activity during pregnancy can also reduce the risk of depression for pregnant women. Pregnant women can register or participate in a series of pregnant women's exercises 
that are broadcast through mass media, such as Youtube so that they can do it at home without having to go to crowded places. Exercises that are recommended for pregnant women include swimming, morning walks, and pregnancy yoga. (Kołomańska, Zarawski and Mazur-Bialy, 2019).

In addition to the relationship between pregnant women and their health workers, pregnant women need to have a relationship good with other pregnant women. It aims to be able to share stories and not feel alone. If before the pandemic they were able to meet directly in the class of pregnant women, during a pandemic like this they can meet through social media such as Whats App, LINE, Instagram, or other media. By forming a group like this can increase positive emotions for pregnant women. The formation of these groups can be facilitated by the midwife who cares for them during pregnancy. In this group, there will be a concern to support each other (Hall et al., 2021).

To maintain the trust of pregnant women, meet with medical personnel, and also protect each other from this virus, health workers use complete Personal Protective Equipment (PPE). This PPE consists of N95 masks, gloves, protective glasses, boots, and hazmat dresses. Medical personnel do this every day to take care of other individuals and themselves (Ministry of Health, 2020).

Tristanti \& Kulsum's research (2021), explains the behavior of prenatal care during the Covid-19 pandemic in Kudus Regency, Central Java in the period June-July 2020 which has undergone various changes, as follows:

1. Frequency of pregnancy checkups

Pregnant women feel worried about having regular check-ups, so they only check the womb if there are complaints. It was explained that antenatal care is important to maintain the period of pregnancy until the birth process by fostering a good relationship between mother and child, detecting complications that can threaten life, preparing for birth, and providing care. WHO recommends pregnant women to have routine pregnancy checkups at least 4 times, namely once in the first trimester, once in the second trimester, and twice in the third trimester. The purpose of prenatal care is to identify and prevent as early as possible any abnormalities that may arise, to improve and maintain the condition of the mother's body to deal with pregnancy, childbirth, and breastfeeding. 
Considering the condition of the Covid-19 pandemic, the schedule for routine examinations for pregnant women is given leeway, at the first pregnancy examination by doctors to screen risk factors through the time contract stage in advance. For pregnant women with PDP or confirmed Covid-19, there is a delay in the ultrasound examination. And further checks by teleconsultation.

2. Places or facilities for pregnancy services

Some pregnant women choose to check their pregnancy at the nearest midwife, they feel that this step is safer and the cost is also cheap. The independent practice of midwives provides standard health services by implementing several policies during a pandemic, namely pregnant women who have no complaints, they should apply information from the $\mathrm{MCH}$ handbook, and it is recommended to go to health facilities if they experience complaints and danger signs. Before carrying out the examination, it is recommended to make a time contract or an appointment with the midwife in advance. Midwives who handle ANC use level 1 Personal Protective Equipment (PPE) (head cover, medical mask, face shield, gloves, work clothes, and shoes) and pregnant women wear masks. For classes for pregnant women, consultation, IEC, and counseling are done online.

3. Planning a pregnancy checkup

Based on the data obtained, pregnant women have made a contract beforehand, namely contacting the midwife before checking and bringing PPE equipment (masks). Before carrying out the examination, pregnant women must plan: find adequate health care facilities or facilities, prepare transportation and assistance facilities, make contracts with selected health workers, prepare Personal Protective Equipment (PPE), bring MCH books, and apply health protocols during inspection process.

4. Implementation of health protocols on pregnancy checkups

In the Independent Midwife Practice (PMB) health protocols have been carried out in providing maternity care: washing hands with soap and running water for 20 seconds (the correct way of washing hands according to the guidelines in the $\mathrm{MCH}$ handbook), using an alcohol-based hand sanitizer at least 70\%, washing hands especially after defecating (BAB) and urinating (BAK) and before eating, avoiding touching your hands to your eyes, nose, and mouth, avoiding contact with sick people, and so on. With the implementation of health 
protocols in pregnancy services, it is hoped that the objectives of pregnancy care can be achieved and pregnant women and midwives are avoided from the transmission of Covid-19.

To get to the new normal era, there needs to be careful preparation from both the government and the community. In the new normal era, all people are required to make peace and live with Covid-19. For pregnant women, to face the new normal era by sticking to health protocols, an increased understanding of antenatal care is very much needed. Antenatal Care (ANC) is a pregnancy examination to improve the physical and mental health of pregnant women, so that they are able to face the period of childbirth, postpartum, breastfeeding, and the return of reproductive health (Yuliani, et al, 2021).

According to Sri Dinengsih, S.ST. M.Kes, all delivery places must have Covid-19 with a minimum standard of Personal Protective Equipment (PPE) level 2. This is charged to midwives in Antenatal Care (ANC) services. But not only that, pregnant women also need to be active in seeking information about standard Antenatal care (ANC) or childbirth during the new normal. With that, pregnant women can minimize the dangers and risks of Covid-19.

The general objective of the activity to increase public knowledge is to be prepared for changes in behavior regarding perceptions in Antenatal Care (ANC) examinations. In addition, it also increases the interaction between pregnant women and health workers to share experiences with Antenatal Care (ANC) examinations.

Based on the information obtained, not a few pregnant women are afraid and anxious to do Antenatal Care (ANC) examinations. They postponed the Antenatal Care (ANC) examination for fear of contracting Covid-19, even though ANC was very important to maintain the health and welfare of the fetus. Thus, Antenatal Care (ANC) examinations need to be carried out while maintaining and implementing strict health protocols so that no party feels disadvantaged.

The World Health Organization (WHO), recommends that Antenatal Care (ANC) visits be carried out at least eight times consisting of the first visit (K1) in the first trimester or gestational age 0-12 weeks, the second visit (K2) in the second trimester or at gestational age 20 and 26 weeks, and the third visit (K3) at 30, 34, 36, 38, and 40 weeks of gestation. The Antenatal Care (ANC) guidelines for the Covid-19 pandemic situation according to the Indonesian Ministry of Health (2020) and POGI (2020) are as follows:

1. Pregnant women in emergency conditions must carry out Antenatal Care (ANC) 
2. Antenatal Care (ANC) examination is not recommended for pregnant women in the first trimester, unless there are complaints or suspicion of an ectopic pregnancy, so an ultrasound is necessary.

3. In the second trimester of pregnancy, Antenatal Care (ANC) examination is carried out with a remote clinic consultation (teleconsultation), unless there are complaints or emergencies.

4. The third trimester pregnancy examination must be carried out 1 month before the expected delivery

The principles of Antenatal Care services for pregnant women (POGI, 2020):

1. At the time of tele-registration, it must be emphasized the importance of pregnant women and their accompanying families using masks when carrying out face-to-face examinations.

2. All staff/health workers use appropriate Personal Protective Equipment (PPE), including head protection, surgical masks, face shields, gowns, gloves and closed shoes.

3. Pregnant women who have close contact and show mild symptoms of COVID-19 infection are required to postpone prenatal examinations for 14 days.

4. Basic evaluations that require in-person meetings, such as blood pressure measurements, laboratory tests, and fetal growth assessment will still be carried out and arranged to be carried out in conjunction with other maternal examinations in order to limit repeated visits to clinics/hospitals.

5. Supplementation of folic acid, calcium, vitamin D and iron is still given according to national recommendations.

6. Pregnant women are advised to count fetal movements independently in the third trimester of pregnancy $>28$ weeks (minimum 10 movements in 2 hours, if the first 2 hours of fetal movement has not reached 10 movements, monitoring can be repeated in the next 2 hours until a maximum of 6 times is done). within 12 hours)). If it has not reached 10 movements for 12 hours, the mother must immediately come to the health facility to ensure the condition of the fetus.

Lack of Antenatal Care (ANC) visits and understanding of the danger signs of pregnancy can harm the mother and fetus, such as bleeding during pregnancy because the danger signs of pregnancy are not detected early on. Optimizing the health of pregnant 
women is very much needed in reducing the incidence of Covid-19 and reducing maternal anxiety during the Covid-19 pandemic.

The current state of the pandemic greatly affects psychosocial conditions in society, changes in traditions or habits, and instability. This certainly causes social turmoil in the community in the form of anxiety, stress, and worry. Of course it is very dangerous for vulnerable groups such as pregnant women. After the implementation of Large-Scale Social Restrictions (PSBB), there has been a decline in social support for pregnant women in Indonesia. As research conducted by Research and Technology-National Research and Innovation Agency of the Republic of Indonesia (RISTEK-BRIN, 2020) in Bekasi City, 17.72\% of pregnant women experience mild anxiety, $13.92 \%$ of pregnant women experience moderate anxiety, and $1.27 \%$ of pregnant women experience anxiety. heavy. Meanwhile, for the stress response, it was found that $13.92 \%$ of pregnant women experienced mild stress, $7.59 \%$ of pregnant women experienced moderate stress, and $2.53 \%$ of pregnant women experienced severe stress (RISTEK-BRIN, 2020).

Meanwhile, in a study in Southeast Sulawesi, $4.4 \%$ of mothers experienced moderate anxiety and $14.3 \%$ experienced severe anxiety. Anxiety that occurs has something to do with the level of mother's age, education, husband's occupation, parity, health facilities, and sources of information about Covid-19.

Some efforts to prevent anxiety can be done with simple things in accordance with the recommendations of the Ministry of Health of the Republic of Indonesia (Kemenkes RI), namely by having healthy living behaviors (washing hands, consuming healthy food), using masks, keeping a distance, avoiding contact with animals such as bats. rats, ferrets, or other animals suspected of being carriers of the Covid-19 virus, and avoiding traveling to Covid-19 danger areas.

Health monitoring can also be done through the $\mathrm{MCH}$ book (Maternal and Child Health) for pregnant women. The MCH handbook is a communication tool and information media needed for pregnant women and health workers during the Covid-19 pandemic (Mardliyana, 2020). Pregnant women can study MCH books at home to get health information to be applied in their daily lives. The information presented by the $\mathrm{MCH}$ handbook includes, among other things, a balanced nutritional menu, rest patterns, hygiene care, physical activity, preparation for childbirth, and danger signs for pregnant women. By studying the $\mathrm{MCH}$ 
handbook, pregnant women can increase their knowledge about healthy living behaviors, so they can avoid the transmission of Covid-19, both for the mother and the fetus.

According to Simbolon (2021), every pregnant woman must take the same precautions as others to avoid infection with Covid-19. This can be done by:

1. Diligently wash your hands using soap and clean running water, or an alcohol-based antiseptic liquid.

2. Keep a distance from other people, at least 1 meter, especially with people who are coughing or sneezing, avoiding touching the eyes, nose and mouth, maintaining respiratory hygiene.

3. Cover mouth and nose when coughing or sneezing with folded elbow or tissue. Then immediately throw the used tissue in a closed trash can.

4. Seek medical attention immediately if fever, cough, or difficulty breathing. Contact via telephone first before going to a health care facility, and follow directions from the local health office.

5. Pregnant women and mothers who have just given birth, including those infected with Covid-19, must undergo routine health care as usual. Examination protocols and eligibility may differ depending on the region.

WHO recommends that pregnant women with Covid-19 symptoms should be prioritized for screening. If they contract Covid-19, they may need special care. Covid-19 can be transmitted from mother to unborn baby or newborn baby, it is not yet known whether a pregnant woman infected with Covid-19 can transmit the virus to the fetus. In this case, cooperation must be established between health workers for pregnant women and pregnant women. Health workers need to always update information and take precautions regarding Covid-19. Because the duties of health workers are always related to sick people, extra security needs to be done, especially for midwives. Because if they become actors who carry the virus to pregnant women, the risk will be very big. Likewise for pregnant women, they must take care of their own health which can be done from home. Raising awareness and education for midwives and pregnant women are equally important to take care of themselves. The challenges of maternity services during a pandemic and the understanding of pregnant women about their condition are an inseparable correlation, and have an impact on each other. 


\section{Maternity Waiting Homes During Covid-19 Pandemic}

During the Covid-19 pandemic, MWHs made adjustments to comply with the applicable health protocols in Indonesia. All staff and patients must have access to and be encouraged to use hand washing facilities as soon as they enter the health facility. Ensure a steady supply of clean water (even if it comes from a bucket if running water isn't available) in every location or room where staff works, as well as in patient waiting areas. Ensure that simple soap is available at each wash station in the health facility, as well as a clean cloth or single-use towel for drying hands. Midwives who provide direct patient care must wash their hands frequently with soap and water.

Hands must be thoroughly washed with soap and water for at least 20 seconds. Wash your hands before seeing any new woman, and then again before any physical examination. Wash again immediately after the examination and after the woman has left. After cleaning surfaces, wash your hands. After coughing or sneezing, wash your hands. Hand sanitizer can also be used, especially as a backup in cases where the water supply is unreliable. Keep your hands away from your eyes, nose, and mouth. All individuals (patients and staff) should be advised to cough into a tissue or their elbow and to wash their hands after coughing and sneezing. During any clinical encounter, midwives should maintain a social distance of two arms lengths. For women who do not have suspected or confirmed COVID-19, physical examination and patient contact should be continued as usual if hand washing is performed before and after. Surfaces used by patients and staff need to be sprayed with a cleaning product (i.e.: $5 \%$ sodium hypochlorite (bleach)) and wiped down with a paper towel or clean cloth in between patients, followed by hand washing.

\section{Conclusion}

From the discussion that has been described above, it is concluded that in the health sector there have been considerable changes. This change is not only carried out by medical personnel, but also needs to be balanced by public awareness. Due to this pandemic, people must pay more attention to themselves, especially for pregnant women. Anxiety will always arise in individuals, so it needs to be countered in various ways that can be done. For pregnant women, it can be done through online examinations and consultations with medical personnel or face to face with strict health protocols. Some activities for pregnant women have been 
changed to online or reduced in intensity as a step to prevent the transmission of the Covid19 virus to pregnant women.

In an effort to overcome the Covid-19 pandemic, it is very important to pay attention to policies in the health sector. The availability of health facilities needs to be ensured in order to be able to serve the community optimally. Control of the Covid-19 outbreak in Indonesia is not only seen from adequate hospital facilities and qualified medical personnel, but also must pay attention to the health system starting from the provision of health services, labor supervision, utilization of information systems, ease of access to medicines, financing of health services, and governance of health services.

The optimization of medical facilities in Indonesia must continue to be carried out. This is done to support the network system that has been carried out from the bottom (Puskesmas). Optimization can be done by seeking remote medicine (telemedicine), making emergency budgets for the health sector, to selecting competent Human Resources (HR) in handling patients so that patients feel safe and trust in the process. To maintain the trust of pregnant women to continue to carry out routine checks, there are many ways that are carried out by medical personnel. One of them is using complete Personal Protective Equipment (PPE) in order to protect each other with others.

In addition, with the reduction in the intensity of examinations during the Covid-19 pandemic, every pregnant woman is provided with communication and information tools as guidelines for obtaining health information to be applied in daily life. Such as by studying the $\mathrm{MCH}$ handbook to increase knowledge about healthy living behavior, so as to avoid the transmission of Covid-19, both for mother and fetus. With this education, pregnant women will understand about preventing Covid-19 infection for pregnant women, pregnancy checkup procedures in the pandemic era, how to maintain the health of pregnant women in the pandemic era, the efforts made when pregnant women are sick in the pandemic era.

\section{References}

Anshari, R., \& Wahyuni, K. I. (2021, January). Edukasi Virtual Terkait Perubahan Perilaku Dalam Masa Pandemi COVID 19. In Konferensi Nasional Pengabdian Masyarakat (KOPEMAS) 2020. 
Buana, D. R. (2020). Analisis Perilaku Masyarakat Indonesia dalam Menghadapi Pandemi Virus Corona (Covid-19) dan Kiat Menjaga Kesejahteraan Jiwa. National Research Tomsk State University, Universitas Mercu Buana.

Choi, K. R. et al. (2020) 'Promotion of Maternal-Infant Mental Health and Trauma-Informed Care During the Covid-19 Pandemic', JOGNN - Journal of Obstetric, Gynecologic, and Neonatal Nursing, 49(5), pp. 409-415. doi:10.1016/j.jogn.2020.07.004.

Damayanti E, Winarsih. (2012). Hubungan Tingkat Pengetahuan Ibu Hamil Tentang RisikoTinggi Kehamilan Dengan Kepatuhan Kunjungan Antenatalcare Di RSUD Pandan Arang Boyolali. http://Publikasiilmiah.Ums.Ac.Id/Bitstream/Handle/123456789/3725/ERNI\%20DAM AYANTI\%20-\%20WINARSIH\%20Fix\%20bgt.Pdf?Sequence=1.diakses pada 30 September 2021.

Derya, Y. A. et al. (2021) 'Pregnancy and birth planning during Covid-19: The effects of teleeducation offered to pregnant women on prenatal distress and pregnancy-related anxiety', Midwifery, 92(January).

Dinkes.(2020).https://dinkes.jatimprov.go.id/userimage/dokumen/JUKNIS\%20PELAYANA N\%20PUSKESMAS\%20PADA\%20MASA\%20PANDEMI\%20COVID-19\%20(1).pdf diakses pada 30 September 2021.

Goa, L. (2017). Perubahan Sosial Dalam Kehidupan Bermasyarakat. SAPA-Jurnal Kateketik dan Pastoral, 2(2), 53-67.

Hall, S. et al. (2021) 'Education in Trauma-Informed Care in Maternity Settings Can Promote Mental Health During the Covid-19 Pandemic', Journal of Obstetric, Gynecologic \& Neonatal Nursing, (January). doi: 10.1016/ j.jogn.2020.12.005.

Ichsan, Burhannudin. (2020). Penerapan Teori Perubahan Perilaku Kesehatan Dalam Menghadapi Pandemi Covid-19: Literature Review https://publikasiilmiah.ums.ac.id/bitstream/handle/11617/12437/13.\%20Burhannudin \%20Ichsan.pdf? sequence=1\&isAllowed $=y$

Indriawan, T., Khofifah, N. A., Shafira, R. D., Sari, D. N., Anatunnisa, J. I., Damayanti, S., ... \& Asyfiradayati, R. (2021). Peningkatan Kesadaran Ibu Hamil ke Pelayanan Kesehatan Saat Pandemi COVID-19 di Desa Gumpang Kecamatan Kartasura. Prosiding Seminar Nasional Kesehatan Masyarakat Universitas Muhammadiyah Surakarta 2021. 
Irianti B. Asuhan Kehamilan Berbasis Bukti. Cetakan ke. Jakarta: Sagung Seto; 2015. 45 p.

Jati, S. P., \& Suparwati, A. (2014). Hubungan Antara Persepsi Ibu Hamil Tentang Mutu Pelayanan Antenatal Dengan Kepuasan Ibu Hamil Di Puskesmas Krobokan Kota Semarang. Jurnal Kesehatan Masyarakat (Undip), 2(2), 157-162.

Kementerian Kesehatan Republik Indonesia. (2020). Info Infeksi Emerging Kementerian Kesehatan RI [Internet]. 2020 [updated 2020 March 30; cited 2020 March 31]. Available from: https://infeksiemerging.kemkes.go.id

Kemenkes RI. (2020). Pedoman Bagi Ibu Hamil Selama Social Distancing. Direktorat Kesehatan Keluarga. Jakarta.

Kemenkes RI. (2020). Pedoman Pelayanan Antenatal, Persalinan, Nifas, Dan Bayi Baru Lahir Di Era Adaptasi Baru. Direktorat Kesehatan Keluarga. Jakarta.

Kołomańska, D., Zarawski, M. and Mazur-Bialy, A. (2019). 'Physical activity and depressive disorders in pregnant women-a systematic review', Medicina (Lithuania), 55(5), pp. 116. doi: 10.3390/medicina55050212.

Mardliyana, Nova Elok. (2020). Optimalkan Buku KIA Ibu Hamil Masa Pandemi Covid-19. $\begin{array}{lll}\text { Universitas } & \text { Muhammadiyah } \quad \text { Surabaya }\end{array}$ surabaya.ac.id/homepage/news_article?slug=optimalkan-buku-kia-ibu-hamil-masapandemi-covid-19

Mirzaqon, Abdi \& Budi Purwoko. STUDI KEPUSTAKAAN MENGENAI LANDASAN TEORI DAN PRAKTIK KONSELING EXPRESSIVE WRITING https://media.neliti.com/media/publications/253525-studi-kepustakaan-mengenailandasan-teor-c084d5fa.pdf

Narwoko, J. Dwi \& Bagong Suyanto, Sosiologi: Teks Pengantar Dan Terapan (Jakarta: Prenadamedia Grup, 2004).

Nurjami.(2020).https://www.ibi.or.id/media/Materi\%20Webinar\%20IBI\%20-\%20USAID\%20J alin\%20Covid19/Seri\%205\%20-\%2010\%20Juni\%202020/PDF\%201\%20Emi\%2010\%20J uni\%20USAID\%20Jalin\%20\%20SITUASI\%20PELAYANAN\%20KB\%20PADA\%20MA SA\%20PANDEMI\%20COVID-19\%20\%26\%20ERA\%20NEW\%20NORMAL\%20compressed.pdf. Diakses pada 30 September 2021. 
Nurrizka, R. H., Nurdiantami, Y., \& Makkiyah, F. A. (2021). Akses Ibu Hamil terhadap Pelayanan Kesehatan di Masa Pandemi COVID-19. Jurnal Kebijakan Kesehatan Indonesia: JKKI, 10(2), 94-99.

Pradana, Anung, Casman, \& Nur'aini. (2020). Pengaruh Kebijakan Social Distancing Pada Wabah Covid-19 Terhadap Kelompok Rentan di Indonesia. Jurnal Kebijakan Kesehatan Indonesia: JKKI, 09(02) : 61-67.

Priyanti, S., Irawati, D., \& Syalfina, A. D. (2020). FREKUENSI DAN FAKTOR RISIKO KUNJUNGAN ANTENATAL CARE: Frequency and Factor Effecting of Antenatal Care Visit. Jurnal Ilmiah Kebidanan (Scientific Journal of Midwifery), 6(1), 1-9.

Rachmawati, A. I., Puspitasari, R. D., \& Cania, E. (2017). Faktor-faktor yang Memengaruhi Kunjungan Antenatal Care (ANC) Ibu Hamil. Jurnal Majority, 7(1), 72-76.

Rahmawati, Y. and Sutrisno (2020) 'Analisis Problematika Maternal Covid-19', in Sutrisno, Romdhoni, A. C., and Andrianto (eds) Memahami Perilaku Covid-19 di Jawa Timur Suatu Tinjauan Multidisiplin. 1st edn. Surabaya: Airlangga University Press, pp. 159-208.

Rofiasari, Linda,Richa Noprianty, Intan Yusita, Yanyan Mulyani, \& Agustina Suryanah. (2020). Pendampingan Kelas Ibu Hamil Dalam Memberikan Motivasi Antenatal Care Sebagai Upaya Untuk Meningkatkan Kesehatan Ibu Dan Janin Di Masa Pandemi COVID-19. Jurnal Peduli Masyarakat. 2(4).

Semen Padang Hospital. (2020). Dokter Ahli Kandungan SPH: Ibu Hamil Lebih Rentan Terkena Covid-19. https://semenpadanghospital.co.id/berita/2020/dokter-ahlikandungan-sph-ibu-hamil-lebih-rentan-terkena-covid-19/ 